\title{
B-cell depletion is ineffective in a patient with granulomatous optic neuropathy
}

Franziska Wagner, MD, Helena Radbruch, MD, Otto W. Witte, MD, and Christian Geis, MD

Neurol Neuroimmunol Neuroinflamm 2018;5:e493. doi:10.1212/NXI.0000000000000493
Correspondence

Dr. Wagner

franziska.wagner@med.uni-jena.de

\section{Case presentation}

A 49-year-old woman had sudden visual loss in her left eye associated with retrobulbar pain and decrease in visual evoked potential amplitude. With suspected optic neuritis, the patient was treated successfully with a 5-day therapy of methylprednisolone (MP) infusion of $1 \mathrm{~g}$ per day (figure 1A). Within several days after MP, partial visual loss reoccurred. MRI showed increased signal and contrast enhancement of the left optic nerve (figure 1, B and C); further diagnostic workup including cerebral and spinal MRI and CSF analysis with oligoclonal bands and soluble Il-2 receptor was normal. Serum antibody screening for aquaporin 4, myelin oligodendrocyte glycoprotein (MOG) and myelin-associated glycoprotein (MAG) was negative. Chest CT did not show signs of hilar adenopathy, interferon-gamma release assays for tuberculosis were negative, and ophthalmologic examination excluded optic retinitis. Optic neuritis relapsed 3 times within the next 4 months and was treated with IV MP and with the suspected diagnosis of atypical relapsing optic neuritis (RON) therapy with azathioprine and overlapping oral MP was initiated (figure 1A). After a stable period of 8 months, azathioprine had to be discontinued because of severe leucopenia. Thereafter, another series of relapses with complete visual loss of the left eye occurred that was refractory to a total dose of $15 \mathrm{~g} \mathrm{MP}$ and additional cycles of plasma exchange after initial partial relief. Since another approach with azathioprine had to be terminated because of leukopenia, B-cell depletion with rituximab together with oral MP was applied. However, further relapses occurred together with continuous deterioration of visual loss in the left eye (figure 1A). In another MRI follow-up, 2.5 years after the initial episode, a granulomatous-like contrast-enhancing process of the left optical nerve was seen (figure 1, D and E). Because there was complete amaurosis in the left eye, we decided to perform a biopsy. Neuropathologic examination revealed a perineural located granulomatous lesion with characteristic multinucleated giant cells, histiocytes and massive lymphocytic infiltration, and small areas of focal noncaseating necrosis (figure 1, F-H). Anti-CD138 stains showed only single plasma cells and no CD20-expressing B cells could be detected, thus confirming effective B-cell depletion with rituximab (figure 1, I and J). Langerhans cell histiocytosis was excluded by CDla-negative histiocytes without granulocytic infiltration (figure $1 \mathrm{~K}$ ). No infectious origin, especially no fungal or mycobacterial origin, could be detected. There was no evidence of systemic sarcoidosis because chest CT, bronchoalveolar lavage, and bronchial biopsies were negative. CSF analysis was repeated and still normal. Thus, based on the clinical presentation and the neuropathologic results, we diagnosed chronic relapsing granulomatous optic neuropathy, and we started immunotherapy with methotrexate to prevent progress of the granulomatous inflammation also to the right optic nerve.

\section{Discussion}

This report provides clinical and histopathologic evidence of a corticosteroid-responsive granulomatous RON. Because RON is a rare disease entity and only limited clinical data are

From the Hans Berger Department of Neurology (F.W., O.W.W., C.G.), Jena University Hospital, Jena; and Department of Neuropathology (H.R.), Charité Universitätsmedizin Berlin, Germany.

Funding information and disclosures are provided at the end of the article. Full disclosure form information provided by the authors is available with the full text of this article at Neurology.org/NN.

The Article Processing Charge was funded by the authors.

This is an open access article distributed under the terms of the Creative Commons Attribution-NonCommercial-NoDerivatives License 4.0 (CC BY-NC-ND), which permits downloading and sharing the work provided it is properly cited. The work cannot be changed in any way or used commercially without permission from the journal. 
Figure Disease course, MRI findings, and histopathology in a patient with granulomatous optic neuropathy
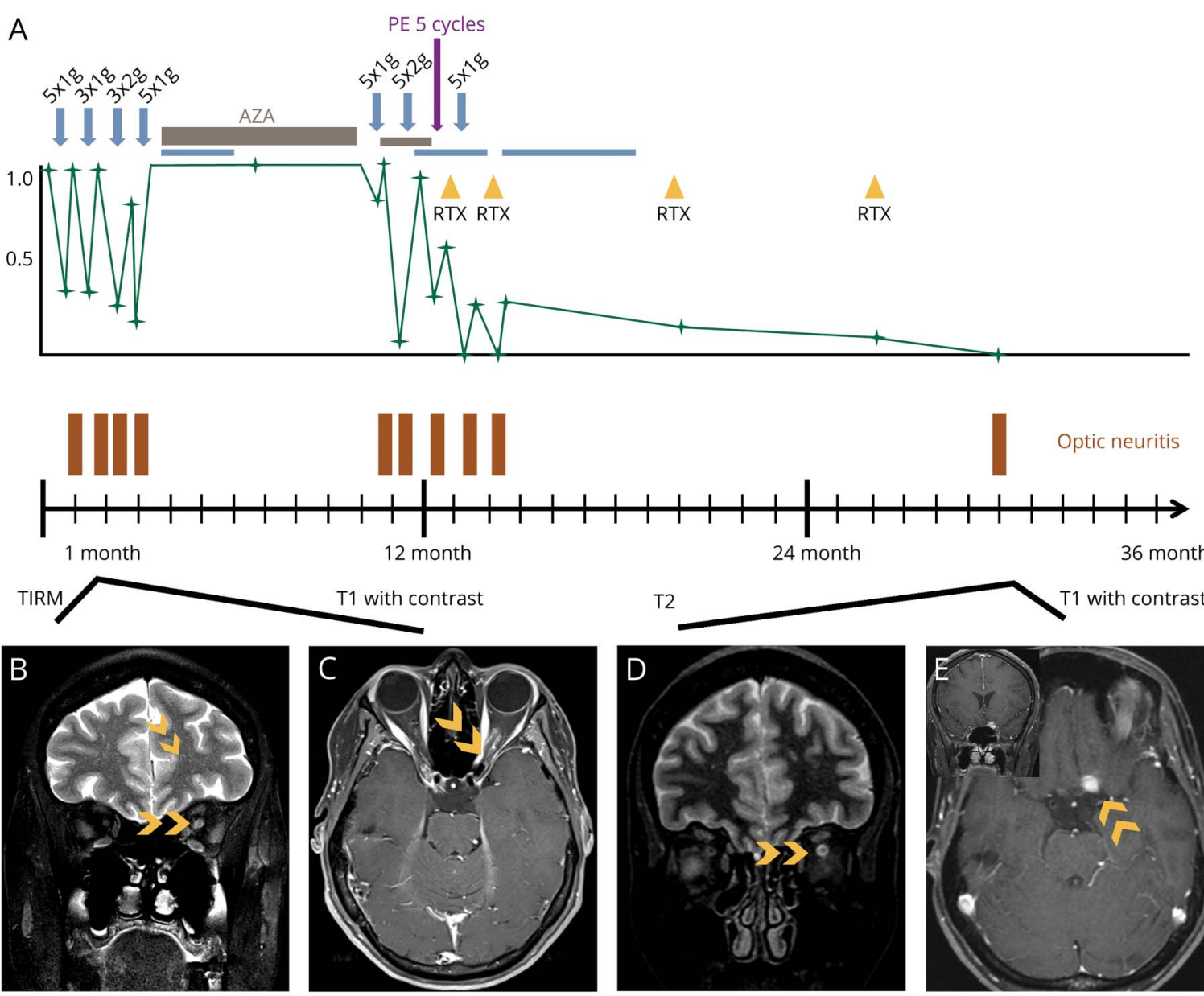

T1 with contrast
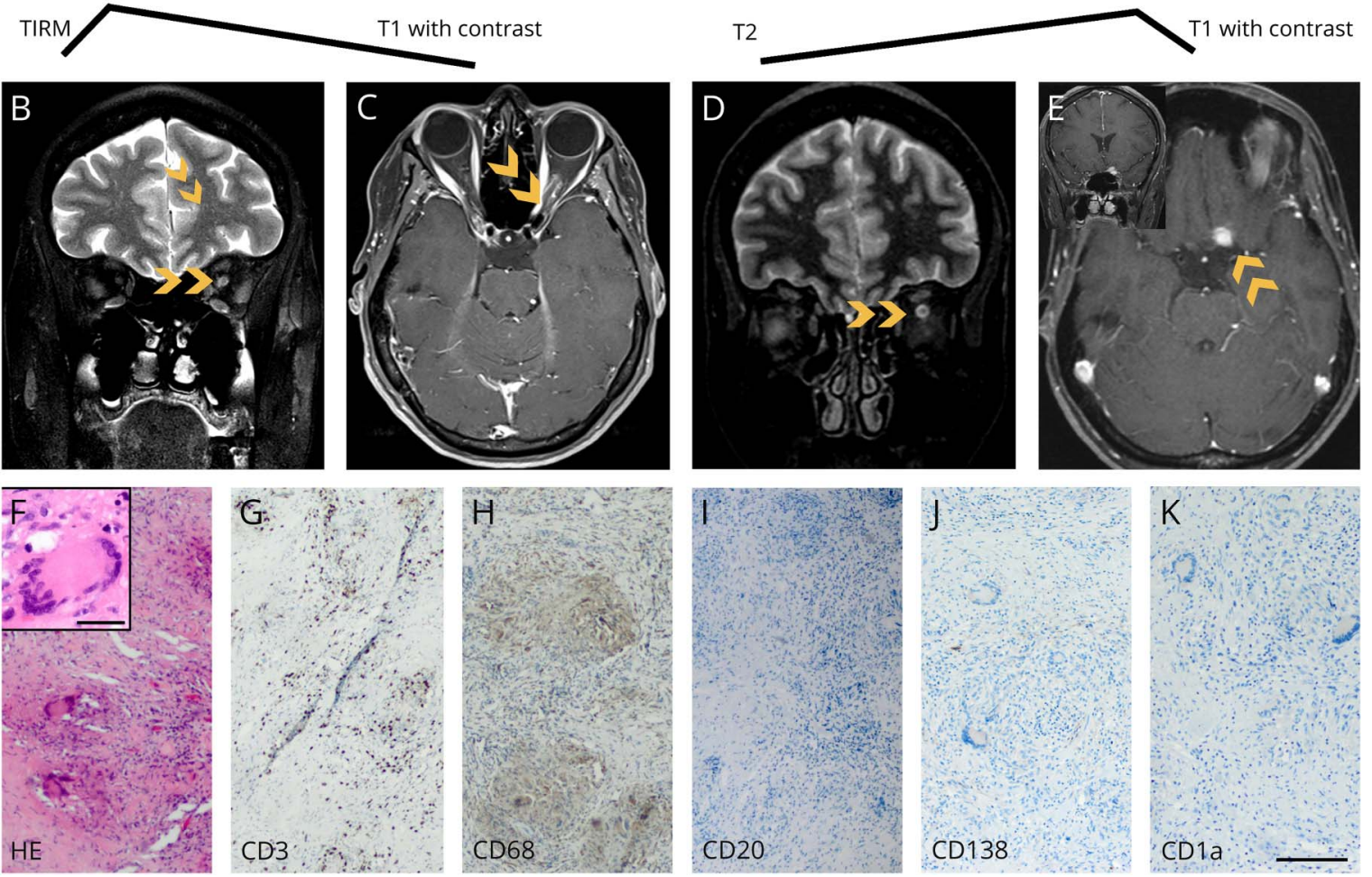

(A) Overview and time scale of the disease course. Black: monthly time scale; red: relapses of optic neuritis; green: visual acuity of the left eye; yellow triangles: application of RTX (1 $\mathrm{g} \mathrm{IV);} \mathrm{blue} \mathrm{arrows:} \mathrm{IV} \mathrm{MP} \mathrm{treatment;} \mathrm{blue} \mathrm{horizontal} \mathrm{markers:} \mathrm{oral} \mathrm{MP} \mathrm{treatment;} \mathrm{gray} \mathrm{horizontal} \mathrm{markers:} \mathrm{treatment} \mathrm{with} \mathrm{oral} \mathrm{AZA;} \mathrm{and} \mathrm{purple}$ arrow: cycle of PE. (B and C) MRI at early stage of disease (2 months after initial symptoms) shows pathologic signal (coronal T2 image, B) and contrast enhancement of the left optic nerve (transversal T1 image after gadolinium, arrowheads). (D and E) Twenty-nine months after symptom onset, MRI shows a contrast-enhancing mass lesion mainly in the retro-orbital part of the optic nerve (arrowheads; coronal TIRM image in D and transversal T1 image after gadolinium in E; inset shows T1 coronal image after gadolinium). (F-K) Serial sections of paraffin-embedded biopsy tissue of the left optic nerve. (F) HE-stained sections of perineuronal granuloma with characteristic multinucleated giant cells (see also inset) and focally dense lymphocytic infiltrations. (G) The inflammatory cells are mainly CD3-positive T-lymphocytes and (H) CD68-positive histiocytes. (I) No CD20-expressing cells can be detected after rituximab treatment, whereas (I) some single CD138-positive plasma cells are present. (K) Langerhans cell histiocytosis is precluded by negative CD1a stains. Scale bar in K (F-K): $100 \mu \mathrm{m}$; inset in F: $5 \mu \mathrm{m}$. AZA = azathioprine; $\mathrm{HE}=$ hematoxylin and eosin; $\mathrm{MP}=$ methylprednisone; $\mathrm{PE}=$ plasma exchange; $\mathrm{RTX}=$ rituximab; $\mathrm{TIRM}$ = turbo inversion recovery magnitude.

available, classification and etiology are still incompletely understood. ${ }^{1}$ Although the rapid response to corticosteroids and pathologic findings with noncaseating granulomas are compatible with neurosarcoidosis, granulomatous RON is regarded as a distinct entity. The clinical characteristics closely resemble those of chronic relapsing inflammatory optic neuropathy (CRION) that has been defined as a painful, relapsing and remitting subtype of optic neuritis responsive to corticosteroids and that often shows a chronic disease course with the need of long-term immunosuppression. ${ }^{2}$ However, in a cohort of RON patients, CRION showed less corticosteroid dependency and a more progressive disease course. ${ }^{3}$ 
Moreover, typical MRI findings in CRION include T2 hyperintensity and contrast enhancement of the optic nerve but are usually not presenting as a contrast-enhancing granulomatous mass. ${ }^{2,4}$ There are few reports on the histopathology of corticosteroid-responsive RON that is mainly classified as chronic relapsing granulomatous optic neuropathy. Similar to our findings, biopsies present as sarcoid-like noncaseating granulomas. ${ }^{5}$ So far, it is unclear whether CRION shares similar neuropathologic characteristics.

Little is known about the pathogenesis and effective immunomodulatory treatment in chronic relapsing granulomatous optic neuropathy except for the usually good response on corticosteroids. Because vision outcome is mostly poor, successful therapy for relapse prevention is needed. Because effective B-cell depletion with rituximab as proven in the granuloma biopsy is inefficient to inhibit granuloma growth and visual loss, exclusive B-cell targeting should not be recommended. Because granulomatous RON shares clear neuropathologic similarities with neurosarcoidosis, infliximab may be a therapeutic option because it is increasingly used as an effective treatment in neurosarcoidosis in patients who do not respond or cannot tolerate methotrexate or azathioprine. ${ }^{6}$

\section{Author contributions}

F. Wagner: patient treatment and diagnostics and writing and drafting of the manuscript. H. Radbruch: performed neuropathologic studies and contributed to the manuscript. O.W. Witte: revised and contributed to the manuscript. C. Geis: patient treatment and diagnostics and writing and revision of the manuscript.

\section{Study funding}

No targeted funding reported.

\section{Disclosure}

F. Wagner reports no disclosures. H. Radbruch received travel funding and/or speaker honoraria from Novartis and Sanofi and received research support from Novartis, Sanofi, and Deutsche Forschungsgemeinschaft. O.W. Witte served on the editorial boards of Das Neurophysiologie-Labor and Zeitschrift für Klinische Neurophysiologie and received research support from the German Research Foundation, Thurigean Ministry for Education and Research, Federal Ministry for Research and Technology, European Union, Else Kroner Foundation, and Jena School for Aging Medicine. C. Geis received travel funding from Merck Serono; was a guest editor of Frontiers Neurology; and received research support from the German Research Council and German Ministry of Education. Full disclosure form information provided by the authors is available with the full text of this article at Neurology.org/NN.

Received February 20, 2018. Accepted in final form June 25, 2018.

\section{References}

1. Petzold A, Plant GT. Chronic relapsing inflammatory optic neuropathy: a systematic review of 122 cases reported. J Neurol 2014;261:17-26.

2. Kidd D, Burton B, Plant GT, Graham EM. Chronic relapsing inflammatory optic neuropathy (CRION). Brain 2003;126:276-284.

3. Benoilid A, Tilikete C, Collongues $\mathrm{N}$, et al. Relapsing optic neuritis: a multicentre study of 62 patients. Mult Scler 2014;20:848-853.

4. Sharma A, Khurana D, Kesav P. MRI findings in chronic relapsing inflammatory optic neuropathy. BMJ Case Rep 2013;2013:bcr2012008100.

5. Frisen L, Lindgren S, MacGregor BJ, Stattin S. Sarcoid-like disorder of the intracranial optic nerve. J Neurol Neurosurg Psychiatry 1977;40:702-707.

6. Gelfand JM, Bradshaw MJ, Stern BJ, et al. Infliximab for the treatment of CNS sarcoidosis: a multi-institutional series. Neurology 2017;89:2092-2100. 


\section{Neurology \\ Neuroimmunology \& Neuroinflammation}

\section{B-cell depletion is ineffective in a patient with granulomatous optic neuropathy}

Franziska Wagner, Helena Radbruch, Otto W. Witte, et al.

Neurol Neuroimmunol Neuroinflamm 2018;5;

DOI 10.1212/NXI.0000000000000493

This information is current as of August 10, 2018

\section{Updated Information \& Services}

References

Subspecialty Collections

Permissions \& Licensing

Reprints including high resolution figures, can be found at:

http://nn.neurology.org/content/5/5/e493.full.html

This article cites 6 articles, 2 of which you can access for free at: http://nn.neurology.org/content/5/5/e493.full.html\#\#ref-list-1

This article, along with others on similar topics, appears in the following collection(s):

Optic nerve

http://nn.neurology.org//cgi/collection/optic_nerve

Optic neuritis; see Neuro-ophthalmology/Optic Nerve

http://nn.neurology.org//cgi/collection/optic_neuritis

Visual loss

http://nn.neurology.org//cgi/collection/visual_loss

Information about reproducing this article in parts (figures,tables) or in its entirety can be found online at:

http://nn.neurology.org/misc/about.xhtml\#permissions

Information about ordering reprints can be found online:

http://nn.neurology.org/misc/addir.xhtml\#reprintsus

Neurol Neuroimmunol Neuroinflamm is an official journal of the American Academy of Neurology.

Published since April 2014, it is an open-access, online-only, continuous publication journal. Copyright

Copyright $\odot 2018$ The Author(s). Published by Wolters Kluwer Health, Inc. on behalf of the American

Academy of Neurology.. All rights reserved. Online ISSN: 2332-7812.

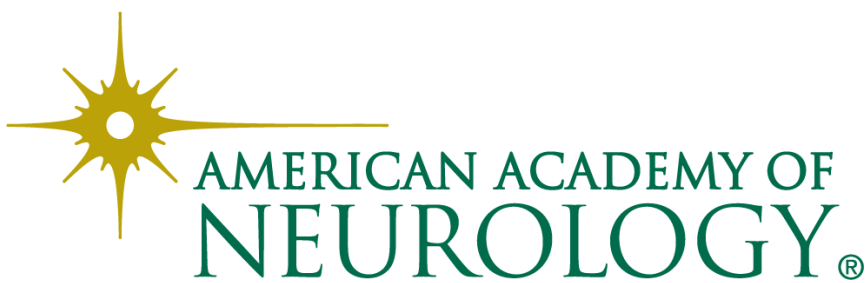

